\title{
Effects of Water Diversion from Yangtze River to Lake Taihu on the Phytoplankton Habitat of the Wangyu River Channel
}

\author{
Jiangyu Dai ${ }^{1}{ }^{(\mathbb{D})}$, Shiqiang $W u^{1, *}$, Xiufeng $W u^{1}$, Wanyun Xue ${ }^{1}$, Qianqian Yang ${ }^{1}$, Senlin Zhu ${ }^{1}$, \\ Fangfang Wang ${ }^{1}$ and Dan Chen ${ }^{2, *}$ \\ 1 State Key Laboratory of Hydrology-Water Resources and Hydraulic Engineering, \\ Nanjing Hydraulic Research Institute, No. 223 Guangzhou Road, Nanjing 210029, China; \\ jydai@nhri.cn (J.D.); xfwu@nhri.cn (X.W.); wyxue@nhri.cn (W.X.); yangqianqian@nhri.cn (Q.Y.); \\ slzhu@nhri.cn (S.Z.); wff08020102@163.com (F.W.) \\ 2 Nanjing Guohuan Science and Technology Co., Ltd. of Nanjing Institute of Environmental Sciences, \\ Nanjing 210042, China \\ * Correspondence: sqwu@nhri.cn (S.W.); chendan_nies@163.com (D.C.); \\ Tel.: +86-25-8582-8203 (S.W.); +86-25-8582-8286 (D.C.)
}

Received: 25 March 2018; Accepted: 31 May 2018; Published: 11 June 2018

\begin{abstract}
To reveal the effects of water diversion from the Yangtze River to Lake Taihu on the phytoplankton habitat of the main water transfer channel of the Wangyu River, we investigated the water's physicochemical parameters and phytoplankton communities during the water diversion and non-diversion periods over the winters between 2014-2016, respectively. During the water diversion periods in the winter of 2014 and 2015, the nutrients and organic pollutant contents of the Wangyu River channel were significantly lower than those during the non-diversion period in 2016. Moreover, the phytoplankton diversities and relative proportions of Bacillariophyta during the diversion periods evidently increased during the water diversion periods in winter. The increase in the water turbidity content, the decrease in the contents of the permanganate index, and the total phosphorus explained only $21.4 \%$ of the variations in the phytoplankton communities between the diversion and non-diversion periods in winter, which revealed significant contributions of the allochthonous species from the Yangtze River and tributaries of the Wangyu River to phytoplankton communities in the Wangyu River. The increasing gradient in the contents of nutrients and organic pollutants from the Yangtze River to Lake Taihu indicated the potential allochthonous pollutant inputs along with the Wangyu River. Further controlling the pollutants from the tributaries of the Wangyu River is critical in order to improve the phytoplankton habitats in river channels and Lake Taihu.
\end{abstract}

Keywords: water diversion from Yangtze River to Lake Taihu; Wangyu River; physicochemical parameters; phytoplankton habitat

\section{Introduction}

Water diversion is a globally historic and popular engineering method for water supply [1]. Since cyanobacterial blooms induced by lake eutrophication have occurred worldwide in the past three decades [2,3], water diversion has also been taken as an emergency engineering measure to relieve this ecological problem in lakes [4-8]. However, water diversion always transfers allochthonous nutrients and species into lakes, and alters their hydrodynamic characteristics and water age. Thus, the ecological effects of water diversion on eutrophic lakes are attracting significant attention [6-10]. 
Lake Taihu is the third largest eutrophic shallow lake located in the Yangtze River Delta region of China, and has affected by frequent cyanobacterial blooms for most of the year [11]. To cope with this problem, water diversion from the Yangtze River to Lake Taihu (WDYT) has been conducted regularly over the past 10 years. Since the nutrient concentrations and biological communities of the Yangtze River are usually different from those of Lake Taihu [9], the allochthonous inputs of nutrients and species bring about potential ecological risks to Lake Taihu [10]. As the main water transfer channel for WDYT, the Wangyu River plays an important role in decreasing the allochthonous nutrients from the Yangtze River and tributaries of the Wangyu River, because the whole distance (over $60 \mathrm{~km}$ ) of this main river channel provides benefits for sedimentation and the degradation of nutrients [11]. However, little attention has been focused on the effects of WDYT on the biological physicochemical habitats of the Wangyu River channel; the spatial variation of nutrients and species along the channel during water diversion periods remains especially unknown.

As the numerous and active biota in freshwaters, phytoplankton are vitally sensitive to the lake conditions such as trophic level and hydrodynamics [12,13]. Moreover, phytoplankton community succession could reflect the effects of environmental changes, and thus, is taken as the eligible index representing the evolution of aquatic ecosystems induced by external disturbance [14]. Since the water level of Lake Tiahu is always lower in winter than the control level established by the Taihu Basin Authority (TBA), most of the water diversion activities are in winter. To reveal the ecological impacts of WDYT on the Wangyu River, this study investigated the physicochemical parameters and phytoplankton communities from the Yangtze River to Lake Taihu in the winter. The ecological effects of WDYT on the water channel were determined by comparing the investigated variables among the diversion and non-diversion periods in the winters of different years. According to the spatial distribution of physicochemical parameters, this study could also provide solutions to improve the environmental management of WDYT.

\section{Materials and Methods}

\subsection{Study Area and Sample Collection}

The study area, from the Yangtze River to Lake Taihu, covers the whole line of the Wangyu River. The Wangyu River connects the Yangtze River and several lakes, such as Lake Jialing, Lake Ezhen, Lake Cao, and Lake Taihu along the whole line (Figure 1). There are two hydrojunctions in the Wangyu River. One is the Changshu hydrojunction near the Yangtze River, while the other is the Wangting hydrojunction near Lake Taihu. There were nine investigated sites distributed along the Wangyu River (Figure 1), from which sites Y and W-8 were located in the upper streams of the Changshu hydrojunction and Wangting hydrojunction, respectively.

The sampling days were 12 January 2014, 16 January 2015, and 19 January 2016. The two sampling days in 2014 and 2015 were on the 52nd and the 80th day of the water diversion activities in winter, respectively. According to the official statistics on the website of WDYT (www.tba.gov.cn:9099), the daily average inflow discharges from Yangtze River on the two water diversion days were $175.9 \mathrm{~cm}^{3} / \mathrm{s}$ and $153.9 \mathrm{~cm}^{3} / \mathrm{s}$, respectively. For each site, 2-L water samples at about a $50-\mathrm{cm}$ depth below the water surface were collected. From the 2-L water sample of each site, a 1-L sample was stored in the sterile plastic bottle and injected with the 1\% Lugol's phytoplankton ending agent for phytoplankton community identification. The other 1-L water sample was used for measuring the physicochemical parameters. 


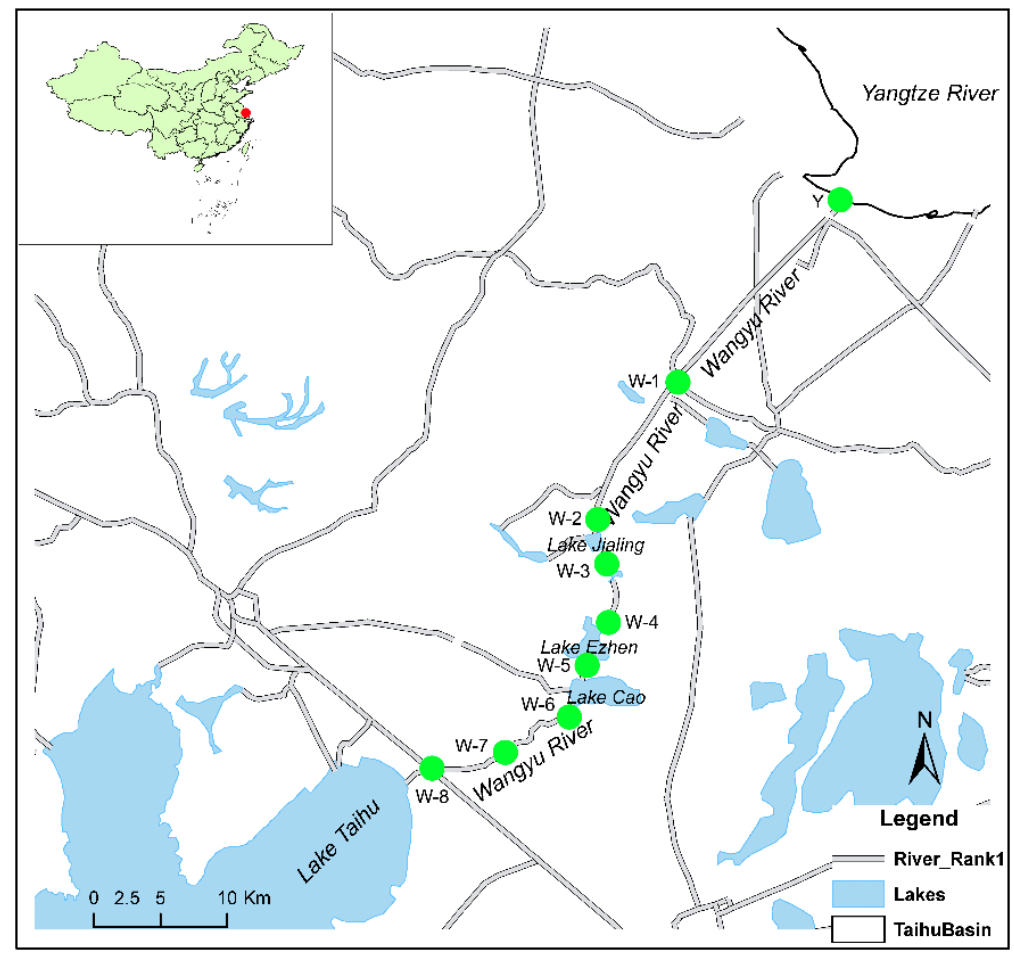

Figure 1. Location of the study area and sampling sites.

\subsection{Measurement of Water Physicochemical Parameters}

The values of water temperature, $\mathrm{pH}$, water turbidity, and dissolved oxygen (DO) content were measured in situ using the HQ30d portable multi-parameter detector (HACH, Shanghai, China). The contents of total nitrogen (TN), total phosphorus (TP), and permanganate index $\left(\mathrm{COD}_{\mathrm{Mn}}\right)$ were all determined according to the Chinese standard Kjeldahl method, the ammonium molybdate spectrophotometric method, and the permanganate method, respectively [15]. About $50 \mathrm{~mL}$ of the original water sample was filtered using the $0.45-\mu \mathrm{m}$ pore size GF/F Whatman ${ }^{\mathrm{TM}}$ filter (GE Whatman, Shanghai, China), and $20 \mathrm{~mL}$ of filtered water was injected into the multi-N/C $3100 \mathrm{TOC} / \mathrm{TN}$ analyzer (Analytik Jena, Jena, Germany) to measure the concentration of dissolved organic carbon (DOC) following the instrument operating instructions [16].

\subsection{Phytoplankton Community Identification}

After over 48 hours of sedimentation, the 1-L Lugol's fixed water sample for each site was concentrated to be $50 \mathrm{~mL}$ in a sterile glass bottle using the separating funnel. A total of $0.1 \mathrm{~mL}$ of the concentrated sample was injected into the 1-mL plankton chamber accounter (Watertools Co., Ltd., Qingdao, China) and placed in the optical microscope Axiovert 200 (CARL ZEISS, Jena, Germany) to uniformly capture 100 random views. The phytoplankton species were identified according to the standard methods of the literature $[17,18]$. The cell abundance of each phytoplankton genus in each water sample was calculated according to the average cell numbers in 100 random views and the magnification times of the microscope [18].

\subsection{Statistical Analysis}

The Shannon-Wiener index is one of many indices of species diversity, and is one based on the concept of evenness or equitability [19]. The Shannon-Wiener index of the phytoplankton communities was calculated using PRIMER-E software (Quest Research Limited, Auckland, New Zealand). The differences of physicochemical parameters and phytoplankton diversities of all of the sampling sites 
in different years were determined by a two-tailed $t$-test. The Venn diagram showing numbers of the common and unique genera among the water samples of the Yangtze River and the Wangyu River during different sampling times was plotted using VennPainter software [20]. The similarities of phytoplankton communities were analyzed by analysis of similarities (ANOSIM) [21] using PRIME-E software. The relative proportion of each phytoplankton phylum was calculated using the percent of the cell abundance of each phylum to the total phytoplankton cell abundance. Redundancy analysis (RDA) was used to reveal the contributions of sensitive physicochemical parameters to variations of phytoplankton communities, which was analyzed using CANOCO 4.5 software [22].

\section{Results and Discussion}

\subsection{Spatio-Temporal Variations of Physicochemical Parameters}

The spatial variations of physicochemical parameters in the winter of different years are shown in Figure 2. The values of DO content and turbidity in the two water diversion periods were significantly higher than those in the non-diversion period of 2016, while the contents of TN, TP, DOC, and COD $\mathrm{Mn}$ in the diversion periods were lower ( $t$-test, $p<0.05, n=9$, Figure 2 ). However, there were also

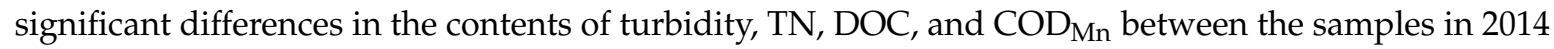

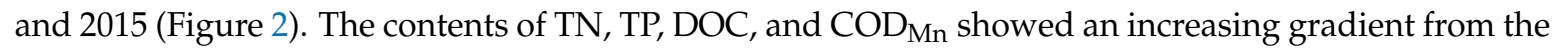
Yangtze River to Lake Taihu, which indicated that there were also water pollutants into the Wangyu River from tributaries or sewage along the river channel. The domestic and agricultural non-point pollution along the Wangyu River should be further controlled in winter, although some management measures had been implemented [23]. Moreover, the particulate inputs from the Yangtze River should be concerned [24].
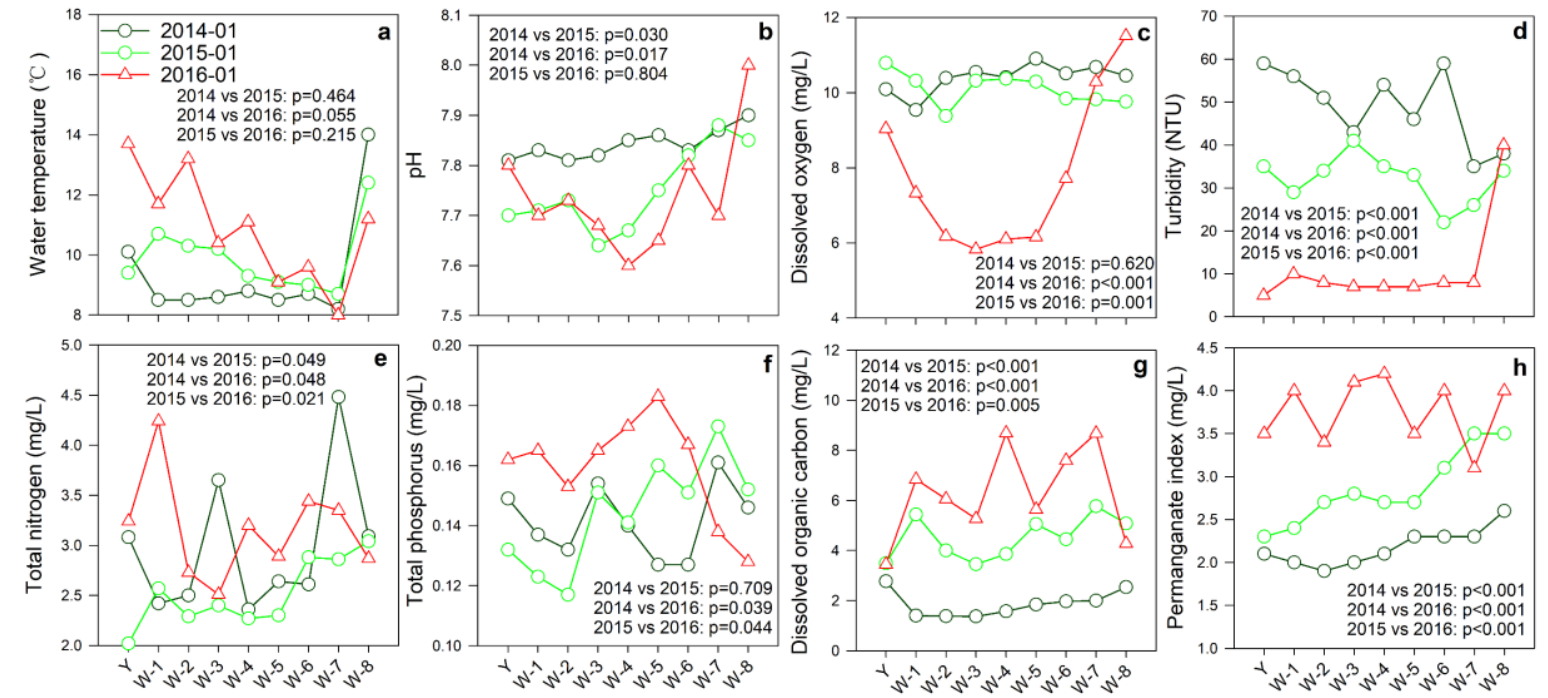

Sampling sites

Figure 2. Spatio-temporal variations of physicochemical parameters along with the Wangyu River channel. (a) water temperature; (b) pH; (c) dissolved oxygen; (d) turbidity; (e) total nitrogen; (f) total phosphorus; (g) dissolved organic carbon; (h) permanganate index.

In winter, because of the low rainfall and the water input from Yangtze River, the water level of the Wangyu River during the water diversion periods were always higher than those during the non-diversion periods. During the non-diversion periods in winter, the nutrients and organic pollutants from the tributaries could flow into the Wangyu River and increase the pollutants concentration of the main channel. However, during the water diversion periods, the higher water level in the Wangyu River could partially prevent the inflows from tributaries [25]. Moreover, the water diversion also 
increased the mobility and oxygen concentration of the water bodies, which could promote the organic pollutants degradation in the Wangyu River [26]. These are the main reasons why the water diversion could decrease the nutrients and organic pollutants in the Wangyu River. Additionally, the degree of decrease should depend on the inflow charges and water quality from the Yangtze River, which were reflected by the differences in the physicochemical parameters of the Wangyu River between the water diversion periods in 2014 and 2015 (Figure 2). However, in this study, it is difficult to conclude that the water diversion in winter decreased the nutrients and organic pollutants concentrations of the Wangyu River channel, since there were also significant differences in the contents of nitrogen and organic pollutants (Figure 2). Further long-term investigation should be conducted to demonstrate the decreasing effects of water diversion on the concentrations of nitrogen nutrients and organic pollutants.

In this study, since the two sampling days in 2014 and 2015 were on the 52nd and the 80th day of the water diversion periods in winter, respectively, the phytoplankton communities and their physicochemical habitat in the Wangyu River had been totally influenced by the water diversion. However, since we did not collect the replicate samples for each period, the collected samples in this study cannot provide sufficient information about the variability of the phytoplankton communities and the physicochemical habit during the short-term water diversion period.

\subsection{Variations in Phytoplankton Diversity and Community Composition}

The spatial variation in the Shannon-Wiener indices of phytoplankton communities in different periods showed the same trend with the peak values at sites W4 or W5 (Figure 3). Since these two sites are located in Lake Ezhen, the high diversity at these two sites might be attributed to the higher biological diversity in lakes than in rivers [27]. Moreover, the phytoplankton diversities during the water diversion periods were significantly higher than those in the non-diversion period ( $t$-test, $p<0.05$, Figure 3), which was probably due to the physicochemical habitat change induced by the water diversion and the inputs of alien phytoplankton species from the Yangtze River. Previous studies also reported that water diversion could increase the species diversity in the water-receiving areas [24]. The ANOSIM results also demonstrated the significant differences in phytoplankton communities among the water diversion and non-diversion periods in winter (Table 1).

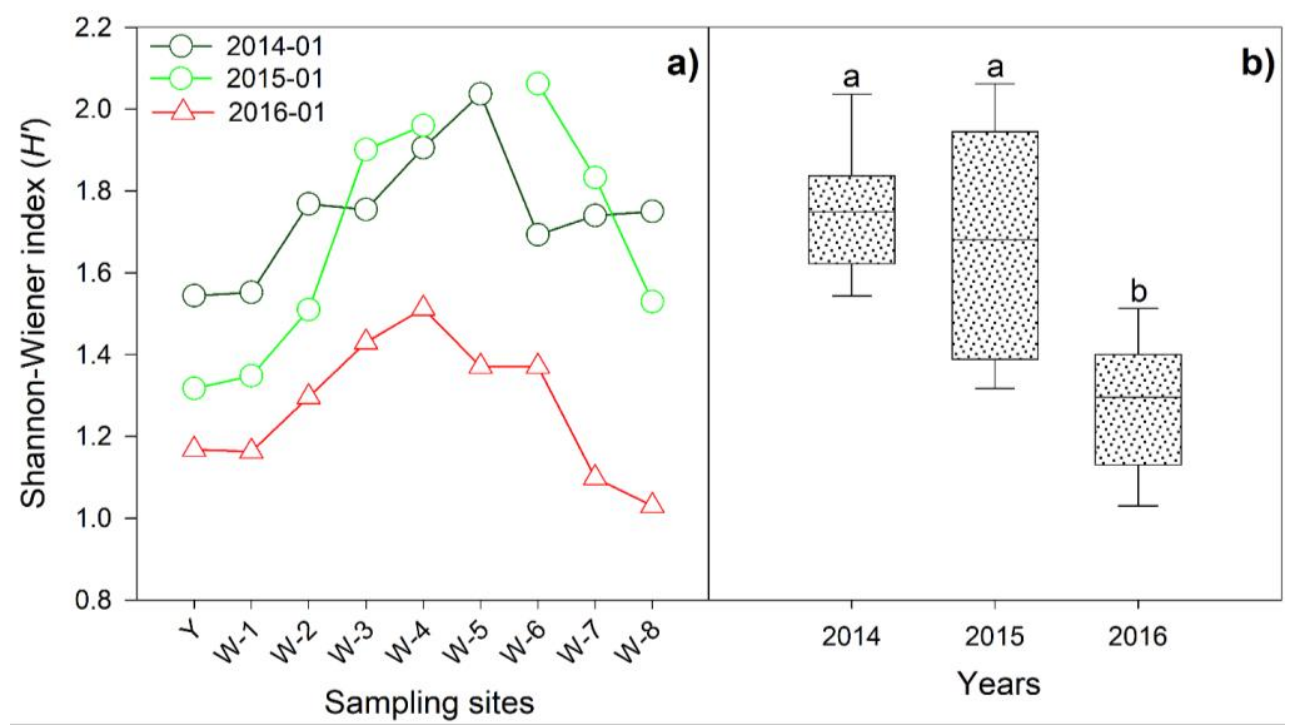

Figure 3. The spatial variations (a) and differences (b) of phytoplankton diversities in the Wangyu River channel. The different letters represent a significant difference. 
Table 1. Analysis of similarity (ANOSIM) comparisons of phytoplankton communities among groups of different years.

\begin{tabular}{ccc}
\hline Group Comparison & $\boldsymbol{R}$ Statistics & $p$ Values \\
\hline $2014-01$ vs. $2015-01$ & 0.132 & 0.067 \\
$2014-01$ vs. $2016-01$ & 0.206 & 0.016 \\
$2015-01$ vs. $2016-01$ & 0.520 & 0.001 \\
\hline
\end{tabular}

The Venn diagram result showed that there were 11 genera found only during the water diversion periods, while two genera were only found during the non-diversion period (Figure 4). Among the 11 genera found only during the water diversion periods, only one genus was also found in the Yangtze River, which indicated that the allochthonous species input from the Yangtze River was not the main reason for the higher diversities of the Wangyu River during the water diversion periods. Moreover, the dominant genera (Pseudoanabaena sp. and Westella sp.) among the 11 unique genera in water diversion periods were not found in the Yangtze River. The Pseudoanabaena sp. is also one kind of toxin-producing algae [28]. The input of these harmful algae genera from the tributaries of the Wangyu River should be of concern, since it threatens the drinking water security of the Wangyu River and Lake Taihu.

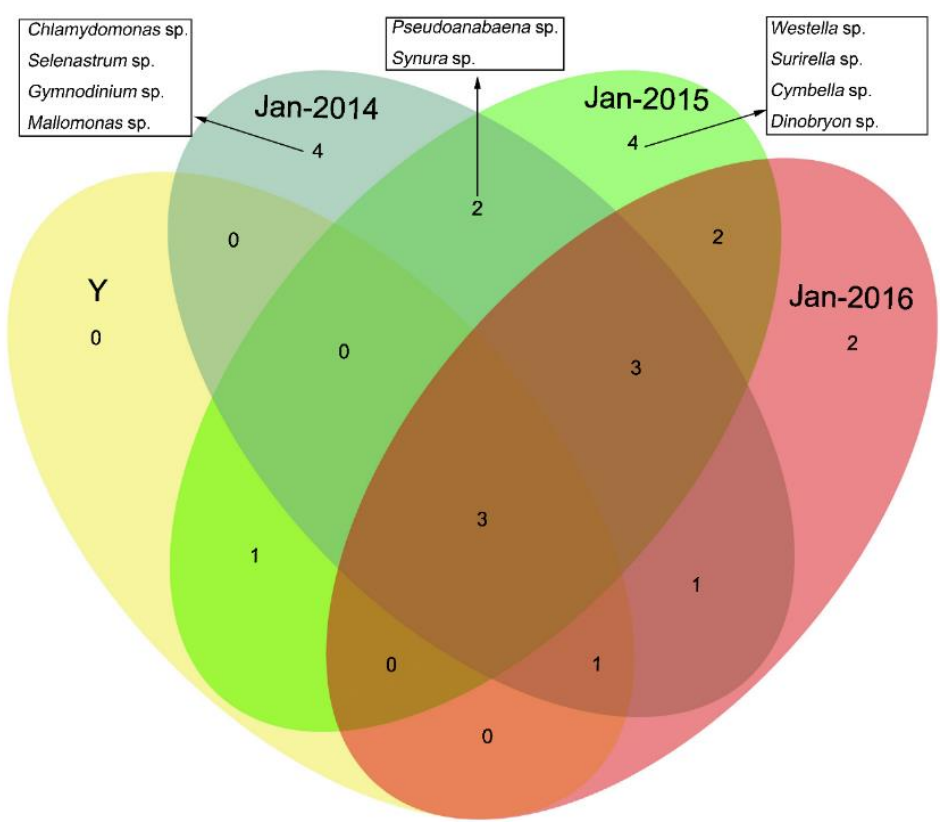

Figure 4. The Venn diagram showing numbers of the common and unique genera among water samples of the Yangtze River and the Wangyu River during different sampling times. Y: All of the samples collected from the Yangtze River; January-2014, January-2015, and January-2016: All samples from the Wangyu River on 12 January 2014, 16 January 2015, and 19 January 2016, respectively. The genera names in the box correspond to the unique genera only found in the Wangyu River during water diversion periods.

The abundances and relative proportions of the phytoplankton phyla are shown in Figure 5. During the two diversion periods in 2014 and 2015, all of the abundances of Cyanophyta, Chlorophyta, and Bacillariophyta increased from the Yangtze River to Lake Taihu, and the Bacillariophyta dominated the phytoplankton communities at all of the sites of the Wangyu River. During the non-diversion period of 2016, Cyanophyta dominated at the sites in the middle and lower reaches of the Wangyu River. Since Bacillariophyta is the dominant phytoplankton phyla in the Yangtze River especially in winter [29-31], the dominance of Bacillariophyta in the Wangyu River might be mainly ascribed to the allochthonous 
species input. In this study, the Cyclotella sp. (24\%-100\%) and Melosira granulate sp. (14.3\%-87.5\%) dominated the Bacillariophyta genera in the Wangyu River during the water diversion periods, while the Cyclotella sp. $(21.4 \%-50 \%)$ and Synedra sp. (14.3\%-100\%) dominated during the non-diversion period (Figure 6). The Cyclotella sp. and Melosira granulate sp. are the common Bacillariophyta genera in the Yangtze River [29]. The input of these two species from the Yangtze River was the main reason explaining the domination of Bacillariophyta in the Wangyu River during water diversion periods. Additionally, both Bacillariophyta and Chlorophyta prefer the flowing water than Cyanophyta [32].

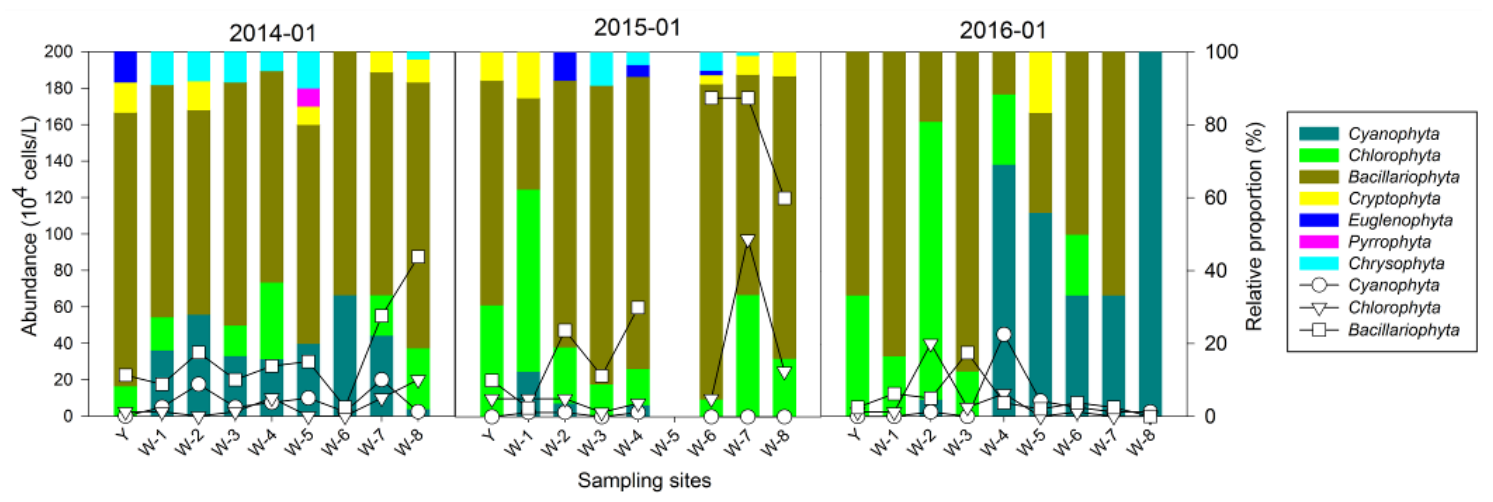

Figure 5. The abundances and relative proportions of phytoplankton phyla in January of different years in the Wangyu River channel.

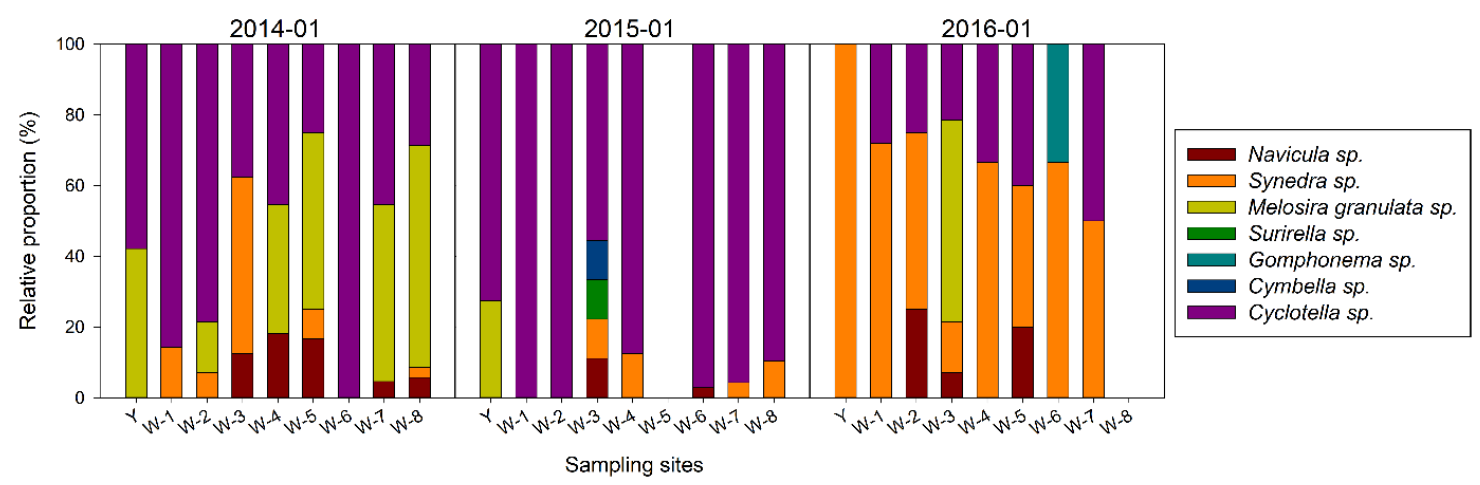

Figure 6. The relative proportions of Bacillariophyta genera in January of different years in the Wangyu River channel.

\subsection{Correlations between Sensitive Physicochemical Parameters and Phytoplankton Communities}

The RDA result showed that the water turbidity $(\mathrm{F}=2.33, p=0.009), \mathrm{COD}_{\mathrm{Mn}}(\mathrm{F}=1.76, p=0.028)$ and TP $(\mathrm{F}=1.56, p=0.036)$ were the significant sensitive parameters that correlated with the spatio-temporal variations of phytoplankton communities (Figure 7). The three sensitive parameters explained $21.4 \%$ of the variations in phytoplankton communities among different years. The higher turbidity, lower $\mathrm{COD}_{\mathrm{Mn}}$, and TP contents shaped the physicochemical habitat of the Wangyu River in ratios similar to those of the Yangtze River. In the Yangtze River, the Bacillariophyta dominated the phytoplankton community in winter [29-31], which is consistent with the phytoplankton communities in the Wangyu River during the water diversion periods in this study (Figure 5). However, these three physicochemical parameters only contributed a small proportion of phytoplankton community variations, most of which might be related to the inputs of the phytoplankton species from the Wangyu River and tributaries along with the Wangyu River. 


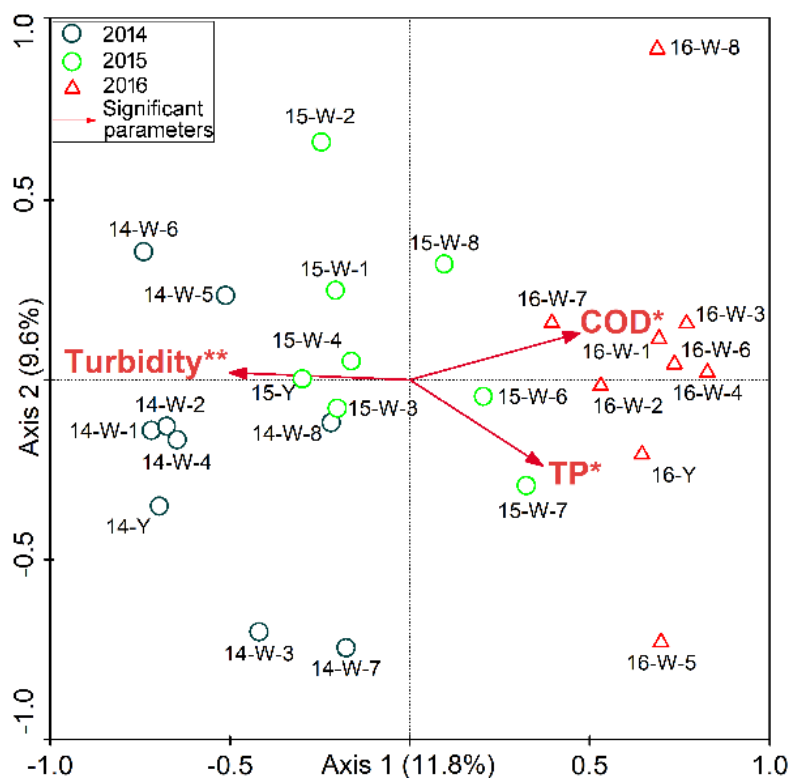

Figure 7. The biplot of the redundancy analysis among sensitive physicochemical parameters and phytoplankton communities in the winter of different years in the Wangyu River channel. COD, permanganate index; TP, total phosphorus. The asterisk marked behind the physicochemical parameters means that the parameter is significantly correlated with the phytoplankton communities $\left(^{*}: p<0.05 ; * *: p<0.01\right)$. The abbreviations such as $14-\mathrm{Y}, 15-\mathrm{Y}$, and 16-Y represent the samples in the winters of 2014, 2015, and 2016, respectively.

\section{Conclusions}

The project of WDYT is usually running in winter. Compared with the non-diversion period in winter, water diversion activities in winter might decrease the contents of nutrients and organic pollutants in the Wangyu River channel. However, the effects of water diversion on the physicochemical parameters should be further investigated. The increasing gradient in contents of nutrients and organic pollutants from the Yangtze River to Lake Taihu revealed the potential allochthonous pollutant inputs along with the Wangyu River, which should be further controlled in winter. The phytoplankton diversity and relative proportions of Bacillariophyta during the diversion periods were evidently increased. However, variations in the contents of water turbidity, $\mathrm{COD}_{\mathrm{Mn}}$, and TP only contributed $21.4 \%$ of the variations in the phytoplankton communities, which indicated that the alien algae species from the Yangtze River and tributaries of the Wangyu River had a more important role in regulating the phytoplankton communities in the Wangyu River. Further controlling pollutants from tributaries of the Wangyu River is critical in order to improve the phytoplankton habitats in the river channels as well as Lake Taihu.

Author Contributions: J.D., S.W. and X.W. designed the field studies; J.D., Q.Y. and F.W. collected and analyzed the samples. J.D., W.X., S.Z. performed data analysis. J.D. and D.C. wrote the paper.

Funding: This research was funded by the National Key R\&D Program of China [2016YFC0401506], the Projects of National Natural Science Foundation of China [51679146; 51479120; 51479121], the Young Elite Scientists Sponsorship Program by Chinese Association for Science and Technology [2017QNRC001], and the Special Research Fund of Nanjing Hydraulic Research Institute [Y117009; Y118001].

Acknowledgments: This work was jointly funded by the National Water Pollution Control and Management of Science and Technology Major Projects (2017ZX07203-002), the Projects of National Natural Science Foundation of China (51679146; 51479120; 51479121), the Young Elite Scientists Sponsorship Program by CAST (2017QNRC001), and the Special Research Fund of Nanjing Hydraulic Research Institute (Y117009; Y118001). Finally, we are grateful to the editor and anonymous reviewers for their constructive comments and helpful suggestions.

Conflicts of Interest: The authors declare no conflict of interest. 


\section{References}

1. Wang, G.; Ouyang, Q.; Zhang, Y. World Water Diversion Projects; Beijing Science Press: Beijing, China, 2009; pp. 1-387.

2. Schindler, D.W. Eutrophication and recovery in experimental lakes: Implications for lake management. Science 1974, 184, 897-899. [CrossRef] [PubMed]

3. Qin, B. Lake eutrophication: Control countermeasures and recycling exploitation. Ecol. Eng. 2009, 35, 1569-1573. [CrossRef]

4. Hosper, S.H. Stable states, buffers and switches: An ecosystem approach to the restoration and management of shallow lakes in the Netherlands. Water Sci. Technol. 1998, 37, 151-164. [CrossRef]

5. White, J.R.; Fulweiler, R.W.; Li, C.Y.; Bargu, S.; Walker, N.D.; Twilley, R.R.; Green, S.E. Mississippi River flood of 2008: Observations of a large freshwater diversion on physical, chemical, and biological characteristics of a shallow estuarine lake. Environ. Sci. Technol. 2009, 43, 5599-5604. [CrossRef] [PubMed]

6. Li, Y.; Acharya, K.; Yu, Z. Modeling impacts of Yangtze River water transfer on water ages in Lake Taihu, China. Ecol. Eng. 2011, 37, 325-334. [CrossRef]

7. Li, Y.; Tang, C.; Wang, C.; Anim, D.O.; Yu, Z.; Acharya, K. Improved Yangtze River diversions: Are they helping to solve algal bloom problems in Lake Taihu, China? Ecol. Eng. 2013, 51, 104-116. [CrossRef]

8. Yao, X.; Zhang, L.; Zhang, Y.; Du, Y.; Jiang, X.; Li, M. Water diversion projects negatively impact lake metabolism: A case study in Lake Dazong, China. Sci. Total Environ. 2017, 613-614, 1460-1468. [CrossRef] [PubMed]

9. Hu, W.; Zhai, S.; Zhu, Z. Impacts of the Yangtze River water transfer on the restoration of Lake Taihu. Ecol. Eng. 2008, 34, 30-49. [CrossRef]

10. Zhai, S.; Hu, W.; Zhu, Z. Ecological impacts of water transfers on Lake Taihu from the Yangtze River, China. Ecol. Eng. 2010, 36, 406-420. [CrossRef]

11. Qin, B.; Zhu, G.; Gao, G.; Zhang, Y.; Li, W.; Paerl, H.W.; Carmichael, W.W. A drinking water crisis in Lake Taihu, China: Linkage to climatic variability and lake management. Environ. Manag. 2010, 45, 105-112. [CrossRef] [PubMed]

12. Padisák, J.; Borics, G.; Grigorszky, I.; Soróczki-Pintér, É. Use of phytoplankton assemblages for monitoring ecological status of lakes within the water framework directive: The assemblage index. Hydrobiologia 2006, 553, 1-14. [CrossRef]

13. Katsiapi, M.; Moustaka-Gouni, M.; Sommer, U. Assessing ecological water quality of freshwaters: PhyCoI-A new phytoplankton community index. Ecol. Inform. 2016, 31, 22-29. [CrossRef]

14. Roelke, D.L.; Li, H.P.; Miller-Deboer, C.J.; Gable, G.M.; Davis, S.E. Regional shifts in phytoplankton succession and primary productivity in the San Antonio Bay System (USA) in response to diminished freshwater inflows. Mar. Freshw. Res. 2016, 68, 131-145. [CrossRef]

15. Jin, X.; Tu, Q. The Standard Methods for Observation and Analysis of Lake Eutrophication, 2nd ed.; Environmental Science Press: Beijing, China, 1990.

16. Aboudi, K.; Álvarez-Gallego, C.J.; Romero-García, L.I. Semi-continuous anaerobic co-digestion of sugar beet byproduct and pig manure: Effect of the organic loading rate (OLR) on process performance. Bioresour. Technol. 2015, 194, 283-290. [CrossRef] [PubMed]

17. Chen, Y.; Qin, B.; Teubner, K.; Dokulil, M.T. Long-term dynamics of phytoplankton assemblages: Microcystis-domination in Lake Taihu, a large shallow lake in China. J. Plankton Res. 2003, 25, 445-453. [CrossRef]

18. Wehr, J.D.; Sheath, R.G.; Kociolek, J.P. Freshwater Algae of North America: Ecology and Classification; Academic Press: Cambridge, UK, 2001.

19. Spellerberg, I.F. Shannon-Wiener Index. In Encyclopedia Ecology; Elsevier: Leiden, The Netherlands, 2008; pp. 3249-3252.

20. Lin, G.; Chai, J.; Yuan, S.; Mai, C.; Cai, L.; Murphy, R.W.; Zhou, W.; Luo, J. VennPainter: A tool for the comparison and identification of candidate genes based on venn diagrams. PLoS ONE 2016, 11, e0154315. [CrossRef] [PubMed]

21. Dai, J.; Gao, G.; Chen, D.; Tang, X.; Shao, K.; Cai, X. Effects of trophic status and temperature on communities of sedimentary ammonia oxidizers in Lake Taihu. Geomicrobiol. J. 2013, 30, 886-896. [CrossRef] 
22. Ter Braak, C.J.F.; Smilauer, P. CANOCO Reference Manual and CanoDraw for Windows User's Guide: Software for Canonical Community Ordination (Version 4.5); Microcomputer Power: Ithaca, NY, USA, 2002.

23. Zhang, L.; Wang, S.; Han, M.; He, Q.; Pan, G.; Wang, C. Nitrogen and phosphorus pollution in the western district of Wangyu River and counter-measures, Taihu Basin. J. Lake Sci. 2010, 22, 315-320.

24. Yang, Q.; Wu, S.; Dai, J.; Wu, X.; Xue, W.; Liu, F. Effects of short-term water diversion in summer on water quality and algae in Gonghu Bay, Lake Taihu. J. Lake Sci. 2018, 30, 34-43.

25. Dai, J.Y.; Wu, S.; Lv, X.; Yang, Q.; Wu, X.; Zhou, J.; Xue, W.; Wang, F. Effect of water diversion on spatial-temporal dynamics of organic pollutants in Gonghu Bay, Lake Taihu. J. Hydroecol. 2016, 37, $39-46$.

26. Zhou, M.; Lei, L.; Dai, Q. Oxygen as a promoter for efficient degradation of organic pollutants by high-temperature and high-pressure electrochemistry. Chem. Commun. 2007, 25, 2645-2647. [CrossRef] [PubMed]

27. Borics, G.; Görgényi, J.; Grigorszky, I.; László-Nagy, Z.; Tóthmérész, B.; Krasznai, E. The role of phytoplankton diversity metrics in shallow lake and river quality assessment. Ecol. Indic. 2014, 45, 28-36. [CrossRef]

28. Zhao, J.; Zhang, K.; Gao, J.; Zhu, J. Characteristics of temporal and spatial distribution of Pseudoanabaena sp. in water transfer route of cascade reservoirs and analysis of influencing factors. Water Resour. Prot. 2016, 32, 111-116.

29. Jiang, Z.; Liu, J.; Chen, J.; Chen, Q.; Yan, X.; Xuan, J.; Zeng, J. Responses of summer phytoplankton community to drastic environmental changes in the Changjiang (Yangtze River) Estuary during the past 50 years. Water Res. 2014, 54, 1-11. [CrossRef] [PubMed]

30. He, Q.; Sun, J.; Luan, Q.S.; Song, S.Q.; Shen, Z.L.; Wang, D. Phytoplankton assemblage in Yangtze River estuary and its adjacent waters in winter time. Chin. J. Appl. Ecol. 2007, 18, 2559-2566.

31. Guo, S.; Sun, J.; Zhao, Q.; Feng, Y.; Huang, D.; Liu, S. Sinking rates of phytoplankton in the Changjiang (Yangtze River) Estuary: A comparative study between Prorocentrum dentatum and Skeletonema dorhnii bloom. J. Mar. Syst. 2016, 154, 5-14. [CrossRef]

32. Yu, Q.; Chen, Y.; Liu, Z.; Giesen, N.V.D.; Zhu, D. The influence of a eutrophic lake to the river downstream: Spatiotemporal algal composition changes and the driving factors. Water 2015, 7, 2184-2201. [CrossRef]

(C) 2018 by the authors. Licensee MDPI, Basel, Switzerland. This article is an open access article distributed under the terms and conditions of the Creative Commons Attribution (CC BY) license (http:/ / creativecommons.org/licenses/by/4.0/). 